\title{
Hubungan Nyeri Punggung Bawah dengan Faktor yang Mempengaruhi pada Pekerja Perusahaan Keramik Divisi Sorting and Production
}

\author{
Magdalena $^{1}$, Flora Rumiati ${ }^{2}$, William ${ }^{2}$, Susanty Dewi Winata ${ }^{3}$ \\ ${ }^{1}$ Fakultas Kedokteran dan Ilmu Kesehatan, Universitas Kristen Krida Wacana, Jakarta, Indonesia \\ ${ }^{2}$ Departemen Fisiologi, Fakultas Kedokteran dan Ilmu Kesehatan, Universitas Kristen Krida Wacana, \\ Jakarta, Indonesia \\ ${ }^{3}$ Departemen Kesehatan dan Keselamatan Kerja, Fakultas Kedokteran dan Ilmu Kesehatan, Universitas \\ Kristen Krida Wacana, Jakarta, Indonesia \\ Alamat Korespondensi : magdalena.2017fk104@ civitas.ukrida.ac.id
}

\begin{abstract}
Abstrak
Nyeri punggung bawah merupakan salah satu aspek kesehatan yang sering terjadi pada para pekerja. Meskipun sudah menggunakan oleh mesin dan teknologi yang canggih, namun masih ada beberapa pekerja bagian sorting dan production yang melakukan manual handling, yang memiliki risiko tinggi terhadap terjadinya nyeri punggung bawah. Jika keadaan ini tidak dideteksi dan ditangani secara dini, ada berbagai dampak negatif yang akan timbul. Penelitian ini bertujuan untuk mengkaji prevalensi nyeri punggung bawah dan faktor risiko yang mempengaruhi pada pekerja di divisi penyortiran dan produksi. Disain penelitian ini adalah cross-sectional yang bersifat deskriptif analitik, berlokasi di PT X dengan besar sampel sebanyak 60 orang (total sampling). Data yang dikumpulkan berasal dari kuesioner Rolland-Morris, pemeriksaan lasegue, observasi lapangan, dan wawancara. Pada penelitian ini digunakan uji statistik univariat dan bivariat. Hasil penelitian didapatkan prevalensi nyeri punggung bawah pada pekerja divisi sorting and production adalah 33,3\%. Hasil uji statistika menunjukkan tidak ada hubungan yang bermakna antara lamanya duduk, beban berat angkat, umur, jenis kelamin, kebiasaan merokok, mengomsumsi kafein, dan kebiasaan senam dengan nyeri punggung bawah pada pekerja di PT X divisi sorting and production ( $p>0,05)$. Hasil yang didapat mengindikasikan perlunya dilakukan pengamatan terhadap penyakit penyerta pada pekerja dan lingkungan tempat bekerja.
\end{abstract}

Kata kunci: divisi penyortiran dan produksi, faktor yang mempengaruhi, nyeri punggung bawah

\section{The Relationship between Low Back Pain and Its Associated Factors among Workers of Sorting and Production Division in Ceramic Factories}

\begin{abstract}
Low back pain often occurs among workers. Even though various processes in ceramic factories have utilized sophisticated machines and technologies, there are still some parts which still have their process handled manually, such as the sorting and production divisions. Workers in these divisions have high risk of low back pain. This condition should be detected and treated earlier to avoid negative impacts. This study aimed to examine the prevalence and the risk factors that affect low back pain among workers in the sorting and production divisions of ceramic factory. Participants in this study were workers in PT X, with a sample size of 60 people. The data were collected by the Rolland-Morris questionnaire, straight leg raising test, field observations, and interviews. Univariate and bivariate statistical tests were used. The results of statistical tests showed that there was no significant relation between each factor (i.e sitting time, lifting weight, age, sex, smoking habits, consuming caffeine, and exercise habits) with low back pain ( $p>0,05)$. The results recommend to observe the comorbidities of workers and the work environment to minimize the risk of low back pain.
\end{abstract}

Keywords: associated factors, low back pain, production division, sorting division.

How to cite :

Magdalena, Rumiati, F., William, W., \& Winata, S. D. Hubungan Nyeri Punggung Bawah dengan Faktor yang Mempengaruhi pada Pekerja Perusahaan Keramik Divisi Sorting and Production. J.Kdokt Meditek. 2021;27(3):249-257. Alvailable from http://ejournal.ukrida.ac.id/ojs/index.php/Meditek/article/view/2122. DOI: https://doi.org/10.36452/jkdoktmeditek.v27i3.2122 


\section{Pendahuluan}

Produktivitas kerja merupakan salah satu faktor utama pemerintah Indonesia dalam bidang industri, untuk meningkatkan kepuasan kerja. Terdapat suatu korelasi antara produktivitas kerja dengan kepuasan kerja. ${ }^{1}$ Ada banyak faktor yang dapat mempengaruhi produktivitas kerja, salah satunya ialah dalam aspek kesehatan, yaitu nyeri punggung bawah atau low back pain. Nyeri punggung bawah adalah nyeri di daerah punggung bawah belakang, yang umumnya terjadi pada daerah bawah margin kosta sampai ke lipat gluteal, atau pada daerah ruas lumbal kelima dan sakralis (L5-S1). ${ }^{2}$ Karena sifatnya yang progresif, keadaan ini dapat mengalami penjalaran ke bagian bawah kaki, sehingga dapat menyebabkan disabilitas dalam hidup. Selain itu, nyeri yang dirasakan ini timbul secara tiba-tiba, yang umumnya akan timbul ketika melakukan perubahan posisi tubuh seperti membungkuk, bangun dari tempat tidur, atau lainnya, dan membaik bila beristirahat. ${ }^{2}$ Nyeri punggung bawah yang terus terjadi akan berdampak besar pada sosial ekonomi pada perusahaan, karena menurunkan produktivitas kerja, tingginya angka absen, serta biaya untuk kesehatan menjadi besar. ${ }^{3}$

\section{World Health Organization mencatat} bahwa, nyeri pinggang merupakan penyakit kedua diantara 20 penyakit lainnya yang tergolong dalam penyakit non-fatal pada tahun 2002-2011. ${ }^{4}$ Selain itu, the Global Burden of Disease Study (GBD) juga mencatat bahwa, low back pain atau nyeri punggung bawah menempati posisi pertama dalam kategori penyakit yang dapat menyebabkan disabilitas dalam hidup, dimana prevalensinya lebih tinggi dibanding dengan disabilitas akibat kecelakaan lalu lintas. ${ }^{5}$ Meskipun nyeri pinggang ini tidak menyebabkan kematian, tetapi dapat menyebabkan disabilitas dalam bekerja atau bahkan melakukan aktivitas ringan seperti berjalan, berdiri, dan lainnya.

\section{Menurut International Association for the} Study of Pain (IASP), nyeri adalah suatu pengalaman perasaan emosional yang tidak menyenangkan, yang berhubungan dengan terjadi secara aktual atau berpotensinya mengalami kerusakan jaringan. ${ }^{6}$ Pengalaman sensoris nyeri bersifat subyektif. Hal ini dikarenakan adanya hal yang mempengaruhi, yaitu faktor biologis, psikis, dan sosial. Hal ini dibuktikan dengan data rekap diagnosa pemeriksaan PT. X yang mencatat bahwa, mialgia atau yang diartikan sebagai pegal-pegal otot, merupakan prevalensi tertinggi ketiga yang terjadi pada pekerja di perusahaan itu. ${ }^{7}$ Data tersebut tidak menyebutkan nyeri punggung bawah sebagai diagnosa, sedangkan dilihat dari kondisi dan beban kerja, divisi ini mempunyai kemungkinan besar untuk terjadinya nyeri punggung bawah. Hal ini disebabkan karena belum ada pemeriksaan yang spesifik mengenai rasa pegal atau nyeri yang dirasakan oleh para pegawai serta belum ada pengamatan dan pemeriksaan rutin akan terjadinya nyeri punggung bawah. Oleh karena itu, penelitian dan pengamatan ini bertujuan untuk untuk mengetahui gambaran distribusi frekuensi dan faktor risiko yang mempengaruhinya. Setelah mengetahui hal tersebut, pihak perusahaan nantinya dapat melakukan pengobatan atau pencegahan agar tidak terjadinya suatu disabilitas akibat kerja.

\section{Metodologi}

Penelitian ini menggunakan desain crosssectional. Subjek penelitian ini adalah pekerja pada divisi sorting and produksi PT X. Kriteria eksklusi yang digunakan dalam penelitian ini adalah pekerja 
yang tidak bersedia mengikuti penelitian, memiliki kelainan tulang belakang seperti kifosis, lordosis, atau skoliosis, memiliki riwayat kelainan ginjal, memiliki riwayat riwayat infeksi herpes zooster pada bagian inguinal, dan pekerja yang sedang diterapi untuk nyeri punggung bawah. Besar sampel yang digunakan dalam penelitian ini sebanyak 60 pekerja dengan menggunakan total sampling, dimana telah ditentukan besar sampel minimal sebanyak 57 pekerja dengan rumus $\mathrm{n}=$ $\frac{\mathrm{Z} \alpha^{2} \times \mathrm{PXQ}}{d^{2}}$

Pengukuran nyeri punggung bawah dilakukan dengan menggunakan kuisioner Rolland Morris yang telah diterjemahkan ke dalam bahasa Indonesia. Nyeri punggung bawah akan dinilai berdasarkan skor total yang didapat dari perhitungan semua komponen yang ada di kuisioner tersebut. Bila didapatkan jawaban $\geq 3$ pada kolom Ya, pekerja dikategorikan mengalami nyeri punggung bawah. Pengukuran nyeri punggung bawah juga didukung dengan pemeriksaan lasegue, pemeriksaan lasegue ini dilakukan pada pasien dalam keadaan terlentang dengan kedua kaki lurus diatas permukaan yang datar. Untuk memastikan posisi pasien dalam keadaan lurus, pemeriksa dapat meletakkan tangan pada tumit dan patella pasien. Setelah itu, pemeriksaan dimulai dengan memfleksikan dan mengangkat kearah atas. Normalnya, akan terbentuk sudut $>70$ derajat. Tetapi, bila pasien merasa nyeri atau tidak mampu mengangkatnya $<70$ derajat, dinyatakan lasegue test positif.

Semua data yang didapatkan dianalisis menggunakan SPSS 24.0 for windows. Uji statistika yang digunakan pada penelitian ini adalah analisis univariat dan bivariat. Analisis univariat digunakan untuk melihat karakteristik responden, distribusi pemeriksaan lasegue, dan prevalensi dari nyeri punggung bawah. Sedangkan untuk melihat adanya hubungan yang mempengaruhi terhadap nyeri punggung bawah digunakan uji chi square, karena variabel pada penelitian ini menggunakan data kategorik.

Penelitian ini telah lolos kaji etik dari Komisi Etik Penelitian FKIK UKRIDA, dengan nomor pengajuan

986/SLKE-

IM/UKKW/FKIK/KE/I/2021.

Tabel 1. Karakteristik Responden Pekerja

\begin{tabular}{|c|c|c|c|}
\hline No. & Variabel & $\mathbf{n}$ & $\%$ \\
\hline \multirow[t]{3}{*}{1.} & Lamanya Duduk & & \\
\hline & $<2$ jam & 25 & 41.7 \\
\hline & $\geq 2$ jam & 35 & 58.3 \\
\hline \multirow[t]{3}{*}{2} & Beban Berat 1x Angkat & & \\
\hline & $<10 \mathrm{~kg}$ & 22 & 36.7 \\
\hline & $\geq 10 \mathrm{~kg}$ & 38 & 63.3 \\
\hline \multirow[t]{3}{*}{3.} & Usia Pekerja & & \\
\hline & $<30$ tahun & 22 & 36.7 \\
\hline & $\geq 30$ tahun & 38 & 63.3 \\
\hline \multirow[t]{3}{*}{4.} & Jenis Kelamin & & \\
\hline & Laki-laki & 57 & 95.0 \\
\hline & Perempuan & 3 & 5.0 \\
\hline \multirow[t]{3}{*}{5.} & Kebiasaan Merokok & & \\
\hline & Tidak & 22 & 36.7 \\
\hline & Ya & 38 & 63.3 \\
\hline \multirow[t]{4}{*}{6.} & Mengomsumsi Kafein & & \\
\hline & Tidak Pernah & 9 & 15.0 \\
\hline & Kadang-kadang $(<3 \mathrm{x} /$ minggu $)$ & 29 & 48.3 \\
\hline & Rutin ( $\geq 3 \mathrm{x}$ dalam seminggu) & 22 & 36.7 \\
\hline \multirow[t]{4}{*}{7.} & Kebiasaan Senam & 5 & 8.3 \\
\hline & Rutin ( $\geq 3 \mathrm{x}$ dalam seminggu) & 30 & 50.0 \\
\hline & Kadang-kadang $(<3 \mathrm{x} /$ minggu $)$ & 25 & 41.7 \\
\hline & Tidak Pernah & & \\
\hline \multirow[t]{3}{*}{8.} & Pemeriksaan Lasegue & & \\
\hline & Positif (<70 derajat) & 22 & 36.7 \\
\hline & Negatif (>70 derajat) & 38 & 63.3 \\
\hline
\end{tabular}

\section{Hasil Penelitian}

Katakteristik responden yang terlibat dalam penelitian ini tercantum pada Tabel 1. Tabel 1 memperlihatkan jawaban dari 60 responden didapatkan jumlah yang berisiko, lebih tinggi dari yang tidak berisiko, yang diantaranya adalah duduk lama $\geq 2$ jam, mengangkat $\geq 10 \mathrm{~kg}$, dan usia pekerja yang berusia $\geq 30$ tahun, serta pekerja yang mempunyai kebiasaan merokok. Pada PT X didapatkan bahwa responden didominasi oleh 
pekerja laki-laki. Untuk kebiasaan mengomsumsi kafein dan mengikuti senam yang diukur dalam satuan minggu, didapatkan hasil responden kategori kadang-kadang menempati posisi tertinggi, dan kategori tidak pernah pada posisi akhir. Pada hasil pemeriksaan lasegue didapatkan 22 pekerja positif nyeri.
Penelitian ini menunjukkan bahwa, sebanyak 20 responden $(33,3 \%)$ ditemukan mengalami nyeri punggung bawah sejak responden mengisi kuisoner. Data ini didapatkan berdasarkan hasil pengisian kuisioner Rolland morris, pemeriksaan lasegue, dan observasi lapangan.

Tabel 2. Analisis Hubungan Nyeri Punggung Bawah dengan Faktor yang Mempengaruhi pada pekerja PT X Divisi Sorting and Production

\begin{tabular}{|c|c|c|c|c|c|c|}
\hline \multicolumn{3}{|c|}{ Variabel } & \multicolumn{2}{|c|}{ Keluhan NPB } & \multirow[t]{2}{*}{ TOTAL } & \multirow{2}{*}{$\begin{array}{l}\text { Chi-square } \\
\text { p value }\left(X^{2}\right)\end{array}$} \\
\hline & & & NPN & Non-NPB & & \\
\hline \multirow[t]{2}{*}{ Lama Duduk } & $<2$ Jam & $\mathrm{n}$ & $5(8,3 \%)$ & $20(33,3 \%)$ & $25(41,7 \%)$ & 0,064 \\
\hline & $\geq 2$ Jam & $\mathrm{n}$ & $15(25,0 \%)$ & $20(33,3 \%)$ & $35(58,3)$ & \\
\hline \multirow[t]{2}{*}{ Berat Beban } & $<10 \mathrm{~kg}$ & $\mathrm{n}$ & $6(10,0 \%)$ & $16(26,7 \%)$ & $22(36,7 \%)$ & 0,449 \\
\hline & $\geq 10 \mathrm{~kg}$ & $\mathrm{n}$ & $14(23,3 \%)$ & $24(40,0 \%)$ & $38(63,3 \%)$ & \\
\hline \multirow[t]{2}{*}{ Usia } & $<30$ Tahun & $\mathrm{n}$ & $8(13,3 \%)$ & $14(23,3 \%)$ & $22(36,7 \%)$ & 0,705 \\
\hline & $\geq 30$ Tahun & $\mathrm{n}$ & $12(20,0 \%)$ & $26(43,4 \%)$ & $38(63,3 \%)$ & \\
\hline \multirow{2}{*}{ Jenis Kelamin } & Laki-laki & $\mathrm{n}$ & $20(33,3 \%)$ & $37(61,7 \%)$ & $57(95,0 \%)$ & 0,209 \\
\hline & Perempuan & $\mathrm{n}$ & $1(1,7 \%)$ & $2(3,3 \%)$ & $3(5,0 \%)$ & \\
\hline Kebiasaan & Tidak & $\mathrm{n}$ & $5(8,3 \%)$ & $17(28,3 \%)$ & $22(36,7 \%)$ & 0,185 \\
\hline Merokok & Ya & $\mathrm{n}$ & $15(25,0 \%)$ & $23(38,3 \%)$ & $38(63,3 \%)$ & \\
\hline Mengomsumsi & Tidak Pernah & $\mathrm{n}$ & $1(1,7 \%)$ & $8(13,3 \%)$ & $9(15,0 \%)$ & 0,238 \\
\hline \multirow[t]{2}{*}{ Kafein } & Kadang-kadang & $\mathrm{n}$ & $12(20,0 \%)$ & $17(28,3 \%)$ & $29(48,3 \%)$ & \\
\hline & Rutin & $\mathrm{n}$ & $7(11,7 \%)$ & $15(25,0 \%)$ & $22(36,7 \%)$ & \\
\hline \multirow[t]{5}{*}{ Kebiasaan Senam } & Rutin & $\mathrm{n}$ & $1(1,7 \%)$ & $4(6,7 \%)$ & $5(8,3 \%)$ & 0,124 \\
\hline & Kadang-kadang & $\mathrm{n}$ & $7(11,7 \%)$ & $23(38,3 \%)$ & $30(50,0 \%)$ & \\
\hline & Tidak Pernah & $\mathrm{n}$ & $12(20,0 \%)$ & $13(21,7 \%)$ & $25(41,7 \%)$ & \\
\hline & & $\mathrm{n}$ & 20 & 40 & 60 & \\
\hline & & & $(33,3 \%)$ & $(66,7 \%)$ & $(100,0 \%)$ & \\
\hline
\end{tabular}

Tabel 2., menunjukkan bahwa tidak ada hubungan bermakna antara faktor yang mempengaruhi dengan kejadian nyeri pungung bawah pada pekerja PT $\mathrm{X}$ divisi sorting and production ( $\mathrm{p}$ value>0,05). Akan tetapi, tabel menunjukkan bahwa kategori faktor yang lebih berisiko memiliki prevalensi lebih tinggi mengalami nyeri punggung bawah dibandingkan kategori faktor yang tidak berisiko.

\section{Pembahasan}

Hasil penelitian pada 60 pekerja ini didapatkan hasil pemeriksaan lasegue yang positif
$36,7 \%$, sedangkan pada pekerja yang mengalami nyeri punggung bawah berdasarkan hasil kuisioner Rolland morris sebanyak 33,3\%. Hal ini menunjukkan bahwa hasil positif pemeriksaan lasegue bukan merupakan suatu pemeriksaan baku untuk nyeri punggung bawah. Dinyatakan nyeri punggung bawah apabila didapatkan hasil positif pada lasegue test dan pengukuran terhadap kuisioner Rolland morris.

Penelitian ini menujukkan bahwa tidak adanya hubungan bermakna antara lama duduk dengan nyeri punggung bawah, karena perusahaan 
ini sudah memiliki pengaturan sistem rolling perbagian pada divisi setiap 2 jam. Hal ini sudah sesuai dengan peraturan ketenagakerjaan yang mengharuskan perusahaan untuk membuat occupational health risk map dan health surveillance disetiap tahunnya, dalam mencegah terjadinya penyakit akibat kerja. Disamping itu, pihak perusahaan juga telah memberikan fasilitas yang memadai, yang sesuai dengan kriteria landasan kerja dalam sikap duduk, dimana tinggi dari cetakan keramik tersebut sudah diatur dengan baik dengan siku dapat membentuk kurang lebih 90 derajat dan juga sandaran kursi yang memungkinkan badan agar tetap tegak. ${ }^{8}$ Penelitian ini sejalan dengan penelitian yang dilakukan oleh Nurwahyuni et al pada tahun 2012. ${ }^{9}$ Yang penting untuk diperhatikan adalah ada atau tidaknya posisi janggal yang terjadi pada saat bekerja. Adams dan Hutton (2012) menyatakan bahwa, faktor mekanis yang dapat menyebabkan low back pain adalah duduk dalam durasi yang lama dengan postur atau posisi yang salah. ${ }^{10}$ Maka dari itu, analisis terhadap ergonomi penting untuk dilakukan seperti melakukan REBA atau Rapid Entire Body Assessment. REBA adalah alat standar untuk menilai posisi atau postur kerja yang berbeda untuk risiko relatif terhadap perkembangan muskuloskeletal. ${ }^{10}$

Tidak ada hubungan bermakna antara beban berat dengan nyeri punggung bawah tidak sejalan dengan beberapa penelitian, salah satunya ialah penelitian yang dilakukan oleh Munir pada tahun 2012. ${ }^{11}$ Hal ini dikarenakan perancangan kesehatan dan keselamatan kerja di perusahaan ini sudah sangat baik. Selain dilakukannya sistem rolling di setiap department pada divisi ini, beban berat dalam $1 \mathrm{x}$ angkat tidak melebihi batas maksimal. Menurut National Institute for
Occupational Safety and Health (NIOSH), berat beban maksimum yang dapat diangkat oleh pekerja adalah $27 \mathrm{~kg}$, baik dilakukan oleh pria maupun wanita. Sedangkan beban berat yang dilakukan pada department palleting ini hanyalah sekitar 17 kg. Penelitian ini juga sejalan dengan penelitian yang dilakukan oleh Heru Septiawan pada tahun 2013, dimana tidak adanya hubungan yang bermakna antara beban berat dengan kejadian nyeri punggung bawah, yang didapati $\mathrm{p}$ value $=1,000 .{ }^{10}$

Hasil penelitian ini menunjukkan bahwa tidak ada hubungan antara umur dengan nyeri punggung bawah. Berbeda dengan penelitian yang dilakukan oleh Munir (2012) di suatu perusahaan $\mathrm{X}$, yang menunjukkan $\mathrm{p}$ value $=0,012$, yaitu adanya hubungan yang bermakna antara umur dengan kejadian nyeri punggung bawah. ${ }^{11} \mathrm{Hal}$ ini disebabkan karena umur pekerja yang berbeda di PT X. Pada PT X, pekerja divisi penyortiran dan produksi didominasi dengan pekerja berusia 20-35 tahun. Meskipun didapati 63,3\% pekerja yang berusia $>30$ tahun, namun hanya 8 diantara 38 pekerja yang berusia diatas 35 tahun. Tarwaka (2004) menyatakan bahwa, keluhan pertama low back pain umumnya terjadi pada usia > 35 tahun dan berkembang seiring bertambahnya usia. ${ }^{12}$ Berbeda halnya dengan kriteria pekerja pada tempat dimana Munir penelitian, dimana didapati 74 pekerja dengan usia 35-45 tahun, dan 31 pekerja yang berusia $>45$ tahun. ${ }^{4} \mathrm{Hal}$ ini berkaitan dengan adanya proses degenerasi berupa pertumbuhan jaringan parut pada diskus intervertebralis dan perubahan pada komposisi nukleus pulposus, yang menyebabkan cairan viskoelastis pada diskus menurun dan ruang antar diskus menjadi dangkal, sehingga tulang belakang mengalami penurunan dalam stabilisasi. ${ }^{13}$ selain itu, seiring bertambahnya umur akan terjadi suatu pengurangan hidrasi, 
proteoglikan, beserta sel pada nukleus palposus. ${ }^{14}$ Tidak adanya hubungan bermakna antara umur dengan nyeri punggung bawah sejalan dengan penelitian yang dilakukan oleh Amod dan temantemannya (2012), mengenai study of occupational factors associated with low back pain in truck drivers of Nagpur City, India, yang didapati hasil uji statistika $\mathrm{p}$ value $=0,060 \cdot{ }^{15}$ Selain itu, penelitian dengan hasil yang serupa juga ditemukan pada penelitian yang dilakukan oleh Febriana di Tahun 2012, yang mencatat bahwa tidak ada hubungan yang bermakna antara umur dengan kejadian low back pain di PT Bakrie Metal Industries. Hal ini dibuktikan dengan hasil uji statistika yang dilakukan uji chi-square dengan ditemukan $\mathrm{p}$ value $=0,724 \cdot{ }^{16}$

Penelitian ini tidak sesuai dengan penelitian yang dilakukan Febrina (2015) dan Rita et al. (2014), menyatakan bahwa adanya hubungan yang bermakna antara jenis kelamin dengan low back pain di PT Bakrie Metal Industries, dengan $\mathrm{p}$ value $=0,046 . .^{16,17}$ Penelitian tersebut juga menyimpulkan bahwa perempuan lebih rentan mengalami low back pain dibanding laki-laki. Hal ini memang sesuai dengan teori, yang menyatakan bahwa secara fisiologis ketahanan otot perempuan lebih lemah dari laki-laki, dimana ketahanan otot wanita hanya $2 / 3$ dari ketahanan otot laki-laki. ${ }^{12}$ Penelitian ini rupanya sejalan dengan penelitian yang dilakukan oleh Adlina (2015), dimana tidak ada hubungan yang bermakna antara jenis kelamin dengan low back pain. ${ }^{18}$ Secara umum, perempuan memang memiliki respon inflamasi dan rasa ambang nyeri yang lebih tinggi dibandingkan dengan laki-laki. Selain itu, hormon gonad yang lebih banyak berada di perempuan juga mempengaruhi rasa nyeri melalui aferen primer, yang dapat meningkatkan aktivitas dari serat $\mathrm{C}$, sehingga nyeri kronik itu dapat timbul. ${ }^{19}$ Akan tetapi, ada berbagai faktor juga yang mempengaruhi rasa nyeri, salah satunya ialah aktivitas fisik. Pada aktivitas fisik berat, jenis kelamin memiliki hubungan yang signifikan terhadap kejadian nyeri punggung bawah. ${ }^{20}$ Tetapi hal ini berbeda dengan adanya regulasi kontrol yang telah diterapkan pada PT X, dimana perempuan di divisi penyortiran dan produksi PT X ini hanya bertugas memonitor alat pengering, pencetakan, dan lain sebagainya. Selain itu, hanya didapati 3 pekerja berjenis kelamin perempuan pada divisi ini. Hal ini yang menyebabkan bahwa tidak ada hubungan yang bermakna antara jenis kelamin dengan nyeri punggung bawah pada pekerja di PT X.

Tidak adanya hubungan yang bermakna antara kebiasaan merokok dengan nyeri punggung bawah sejalan dengan penelitian yang dilakukan oleh Febrina (2015) di PT Bakrie Metal Industries dan Heru (2013) di PT Mikroland Development juga dengan $\mathrm{p}$ value $=0,548$, sedangkan ditemukan 93,9\% pekerja yang merokok di perusahaan tersebut. ${ }^{10}$ Secara teori, nikotin yang terkadung pada rokok menyebabkan penurunan perfusi darah pada korpus vertebra yang akan mengganggu metabolisme diskus intervertebralis dan juga menurunkan mineral tulang, yang akan menyebabkan kerapuhan atau bahkan mikrofraktur. ${ }^{21}$ Manusia yang sudah mempunyai kebiasaan merokok bahkan sulit untuk berhenti meski sudah diberikan larangan atau edukasi yang menakutkan. Akan tetapi, Pada PT X ini, telah diberlakukan kebijakan terkait pekerja hanya boleh merokok di jam istirahat dan tidak diperbolehkan untuk keluar dari kawasan pabrik. Hal ini mengartikan bahwa, pekerja hanya mendapat waktu kurang lebih 30 menit untuk merokok dalam 
8 jam sehari, yang dapat mengurangi risiko terjadinya nyeri punggung bawah. Sedangkan pengaruhi rokok dengan nyeri punggung bawah juga dipengaruhi oleh durasi dan jumlah batang rokok yang dikomsumsinya.

Berbagai penelitian menyatakan bahwa kafein dapat digunakan sebagai medikasi bagi penderita nyeri kepala. Hal ini disebabkan karena efek dari kafein yaitu sebagai antagonis reseptor adenosin A1, A2A, dan A2B yang banyak terletak pada korda spinalis, thalamus, dan bagian supraspinal lainnya. ${ }^{22}$ Selain itu, kafein memiliki efek vasokonstriksi terhadap pembuluh darah, yang menyebabkan iskemik dan penurunan suplai oksigen ke otot dan pembuluh darah yang berada di daerah lumbal dan sakrum, sehingga dapat terjadi penumpukan asam laktat. Penelitian ini menunjukkan bahwa tidak ada hubungan bermakna antara mengomsumsi kafein dengan nyeri punggung bawah ( $\mathrm{p}$ value $>0,05$ ). Penelitian ini sesuai dengan penelitian yang dilakukan oleh Adlina (2015), dimana didapatkan $\mathrm{p}$ value $=0,841$, yang menyatakan bahwa tidak adanya hubungan yang bermakna antara mengomsumsi kafein dengan low back pain pada mahasiswa FKIK UIN. ${ }^{18}$ Tidak adanya hubungan ini disebabkan karena kebiasaan mengomsumsi kafein yang menyebabkan nyeri punggung bawah juga dipengaruhi oleh faktor durasi dan volume kafein yang dikomsumsi. Jika seseorang tersebut belum mempunyai suatu pengalaman sensorik pada nyeri atau belum terjadi atau berpotensi terjadi kerusakan jaringan, ia tidak akan merasakan rasa nyeri tersebut.

Pekerja yang tidak pernah mengikuti senam menempati posisi tertinggi dibandingkan dengan pekerja yang rutin atau kadang mengikuti senam. Hasil uji statistika juga menunjukkan bahwa tidak ada hubungan yang bermakna antara kebiasaan senam dengan nyeri punggung bawah pada setahun terakhir di PT X. Penelitian ini sejalan dengan penelitian yang dilakukan oleh Adlina (2015) dan Febrina (2015) yang mencatat bahwa, tidak ada hubungan yang bermakna antara kebiasaan senam dengan low back pain. ${ }^{16,18}$ Banyak pekerja di PT X ini tidak dapat mengikuti senam secara rutin karena adanya pengaturan jam shift dari divisi sorting and production, dimana dalam 3 hari, pekerja hanya mendapatkan porsi 1 hari shift pagi. Sedangkan perusahaan hanya mengadakan senam di jam pagi, sehingga hanya pekerja dengan official hour dan pekerja yang mendapat shift pagi, yang umumnya mengikuti senam di perusahaan. Umumnya senam pagi tersebut dapat diikuti oleh pekerja yang telah menyelesaikan jam shift malam. Akan tetapi, beberapa pekerja menyatakan bahwa, mereka sudah terlalu lelah dan mengantuk bila harus mengikuti senam setelah bekerja di shift malam. Untuk menindaklanjuti program tersebut, perusahaan dapat memberikan prinsip reward and punishment, yaitu dengan memberikan apresiasi pada pekerja yang rutin mengikuti kebiasaan senam, dan memberikan sanksi berupa teguran atau edukasi terkait pentingnya kebiasaan senam, pada pekerja yang jarang atau bahkan tidak pernah mengikuti senam di perusahaan.

Ada berbagai keterbatasan dalam penelitian ini, diantaranya ialah penelitian ini yang hanya menggunakan kuisioner Rolland Morris yang umumnya bersifat subyektif dan tidak bisa menilai faktor psikologis dari pekerja. Selain itu, nyeri punggung bawah disebabkan oleh multifaktor. Pada penelitian ini, tidak dilakukan penelitian terhadap faktor lingkungan dari perusahaan tersebut. 


\section{Simpulan}

Data penelitian menunjukkan dari 60 responden, didapatkan pekerja yang tidak mengalami nyeri punggung bawah lebih banyak dibandingkan yang mengalami. Tidak ada hubungan yang bermakna antara nyeri punggung bawah dengan faktor yang mempengaruhi pada pekerja PT X divisi sorting and production. Nyeri punggung yang dialami oleh pekerja bukan disebabkan karena faktor individu dan okupasi. Untuk mengetahui faktor penyebab, dapat dilakukan pengamatan secara detail terhadap individu dan lingkungan dari tempat kerja.

\section{Daftar Pustaka}

1. Nuszep, A. Hubungan antara kepuasan kerja dengan produktivitas kerja karyawan. Jurnal PSYCHE. 2012;1(1):50-60.

2. Douglas G, Nicol F, Robertson C. History taking. In: Macleod's Physical Examination. Churchill Livingstone: ELSEVIER, 2013. p. 12.

3. Fauci, Anthony S, MD, et all. Low back pain. In: Harrison's principles of internal medicine. Volume 1. New York: McGraw-Hill Health Profession Division; 2015.

4. WHO Methods and Data Sources for Global Burden of Disease Estimates 2000-2011. [dikutip 2 Maret 2020]. Diunduh dari http://www.who.int/healthinfo/statistics/Glob alDALYmethods_2000_2011.pdf.

5. GBD 2016 DALYs, HALE Collaborators. Global, regional, and national incidence, prevalence, and years lived with disability for 328 diseases and injuries for 195 countries, 1990-2016: A systematic analysis for the Global Burden of Disease Study 2016. Lancet; 2017. p. 1211-59.

6. Adams JD. The effects of yin, yang, and qi in the skin on pain. Medicines (Basel). 2016;3(1).

7. Firdaus B. Data rekap diagnosa pekerja PT Arwana Nuansa Keramik. Cikande: Arwana Nuansa Keramik; 2020.

8. Salvendy G. Handbook of human factors and ergonomics. $4^{\text {th }}$ edition. Canada: John Wiley and Sons; 2012.

9. Nurwahyuni, Djajakusli R, Naiem F. Faktor yang berhubungan dengan keluhan nyeri punggung bawah pada pekerja bongkar muat barang Pelabuhan nusantara kota Pare-Pare tahun 2012. [skripsi] Makassar: Fakultas Kesehatan Masyarakat Universitas Hassanudin; 2012.

10. Septiawan H. Faktor yang berhubungan dengan keluhan nyeri punggung bawah pada pekerja bangunan PT Mikroland Semarang. [skripsi]. Semarang: Universitas Negeri Semarang; 2013;2(2).

11. Munir S. Analisis nyeri punggung bawah pada pekerja bagian final packing. [tesis]. Jakarta: Universitas Indonesia; 2012.

12. Tarwaka, dkk. Ergonomi Untuk Keselamatan Kesehatan Kerja dan Produktivitas. [skripsi]. Surakarta: Universitas Islam Batik; 2015.

13. Agur, AMR, Dalley, Arthur F, Moore KL. Vertebral column. In: Clinically oriented anatomy. China: Wolters Kluwer; 2018. p. 301-11.

14. Oichi T, Taniguchi Y, Oshima Y, Tanaka S, Saito T. Pathomechanism of intervertebral disc degeneration. JOR Spine. 2020;3(1).

15. Amod BA, Shubhangi G,Sandeep, Prashant T. Study of Occupational Factors Associated with Low Back Pain in Truck Drivers of Nagpur City, India. International Journal of Medical and Health Sciences. 2012;1(3): 53 60.

16. Maizura F. Faktor-faktor yang berhubungan dengan keluhan nyeri punggung bawah (NPB) pada pekerja di PT. Bakrie Metal Industries tahun 2015. [skripsi]. Jakarta: Universitas Islam Negeri Syarif Hidayatullah; 2015.

17. Furtado RNV, Luiza HR, Arruda BA, Descia FJ, Martucci CEM, Debora CS. Nonspecific low back pain in young adults: Associated risk factor. Brazil: Elsevier; 2014.

18. Zahra A. Hubungan indeks massa tubuh, jenis kelamin, kebiasaan minum kopi, dan kebiasaan olahraga dengan kejadian low back pain pada mahasiswa kedokteran FKIK UIN. [skripsi]. Jakarta: FKIK Universitas Islam Negeri Syarif Hidayatullah; 2015.

19. Basch MC, Chow ET, Logan DE, Schechter NL, Simons LE. Perspectives on the clinical significance of functional pain syndromes in children. Journal of pain research. 2015;8: p. 675-86.

20. Triki M, Koubaa A, Masmoudi L, Fellmann N, Tabka Z. Prevalence and risk factors of back pain among undergraduate students of a sport and physical education institute in Tunisia. Libyan Journal of Medicine; 2015. 
21. Andini, F. Risk factors of low back pain in workers. Workers J MAJORITY. 2015;4(1).

h. $12-9$.

22. Auliansyah D, Carolia N. Peran kafein dalam tatalaksana nyeri kepala dan kafein withdrawal. J Agromedicine Unila. 2018;5(2). 